\title{
ANALISIS KEBUTUHAN DALAM PEMBELAJARAN IPA KIMIA UNTUK PENGEMBANGAN BAHAN AJAR KIMIA SMP DI DKI JAKARTA
}

Sondang N Sihombing dan Marheni

Jurusan Kimia, Fakultas MIPA, Universitas Negeri Jakarta, Jl. Pemuda No. 10 Rawamangun Jakarta 13220, Indonesia

sondangunj@yahoo.com

\begin{abstract}
Abstrak
Tujuan penelitian ini adlah untuk mengetahui kebutuhan guru dalam pembelajaran IPA khususnya kimia steleah diberlakukannya kurikulum tingkat satuan pendidikan atau kurikulum 2006 yang kemudian akan dijadikan sebagai acuan untuk pengembangan bahan ajar kimia di SMP. Data dikumpulkan dengan menggunakan angket melalui teknik purposive sampling. Dari hasil analisis data dapat dibuat kesimpulan sebagai berikut 1) kebutuhan pembelajaran IPA-kimia di SMP cukup bervariasi tetapi pada umumnya perlu bahan ajar yang kontekstual 2)isu-isu penting yang sedang marak seperti zat warna makanan, pengawet, pemanis yang ada dalam jajanan siswa perlu dijadikan bahan kajian diskusi di kelas, 3) kendala yang dihadapi guru dalam pembelajaran antara lain terbatasnya waktu, latar belakang pendidikan guru yang tidak menunjang dan terbatasnya bahan ajar yang sesuai dengan karakteristik siswa serta kurangnya sarana prasarana untuk menunjang praktikum
\end{abstract}

Kata kunci : analisis kebutuhan, bahan ajar, Kimia

\section{PENDAHULUAN}

Masalah yang sedang kita hadapi dalam pendidikan IPA termasuk kimia bukan hanya rendahnya hasil belajar tetapi juga rendahnya kualitas pembelajaran yang berlangsung. Wiyanto (2007:389) mengatakan bahwa pembelajaran sains di SMP dan SMA hanya menekankan pada isi dan bukan pada proses. Pembelajaran cenderung monoton dan aktivitas sains rendah. Upaya untuk memperbaiki pembelajaran telah dilakukan melalui perubahan kurikulum, seperti kurikulum 1984, kurikulum 1994, kurikulum 2004 (kurikulum berbasis kompetensi) dan sekarang kurikulum 2006 (kurikulum tingkat satuan pendidikan yang kemudian dikenal dengan KTSP). Namun perubahan kurikulum dengan konsep yang bagus belum dapat secara serta merta mengubah proses pembelajaran yang dilaksanakan guru di sekolah. Hal ini disebabkan karena guru belum dapat menterjemahkan tujuan kurikulum ke dalam program pembelajaran. Kekurang mampuan ini kemungkinan disebabkan oleh beberapa hal, seperti kurangnya pemahaman tentang kurikulum baru yang berlaku, beban tugas guru yang cukup padat serta rendahnya kompetensi professional guru.

Pengenalan ilmu kimia dalam kurikulum sains berbasis kompetensi merupakan salah satu langkah awal pembaharuan dalam dunia pendidikan terutama di sekolah menengah pertama (SMP). Pada kurikulum sebelumnya ilmu kimia hanya diajarkan di SMA. Pembelajaran kimia di SMP yang terintegrasi dalam kurikulum sains berbasis kompetensi memiliki karakteristik khas yang menyediakan pengalaman belajar untuk memahami konsep dan proses kimia yang bermanfaat bagi siswa dalam mempelajari kimia dan alam sekitar.

Saat ini berlaku kurikulum 2006 (Kurikulum Tingkat Satuan Pendidikan ) yang memungkinkan penyesuaian program pendidikan dengan kebutuhan dan potensi yang ada di daerah dengan tetap mengacu pada standar nasional pendidikan terutama standar isi (SI) dan standar kompetensi lulusan (SKL). Kurikulum baru ini tidak saja menuntut keaktifan guru dalam memilih dan menciptakan kegiatan siswa sesuai dengan lingkungan siswa tetapi juga menuntut kerjasama dari semua komponen sekolah. Karena itu kesiapan sumber daya manusia dan 
sarana serta prasarana yang diperlukan dalam pelaksanaan pembelajaran kimia menjadi perhatian dan tanggung jawab bersama semua komponen sekolah untuk dapat membentuk kompetensi lulusan yang diharapkan.

Keberadaan bahan ajar baik berupa buku, lembar kerja sangat diperlukan untuk membantu guru dan siswa dalam pembelajaran. Sementara buku ajar yang beredar selama ini walaupun diberi label sesuai dengan kurikulum (terbaru) pada sampulnya, namun isinya tidak mengalami perubahan secara bermakna. Ini berarti pengembangan bahan ajar yang sesuai dengan pengembangan kurikulum terbaru menjadi penting dilakukan untuk meningkatkan mutu bahan ajar dan keberhasilan pelaksanaan kurikulum.

Alasan lain dilakukannya penelitian ini adalah temuan hasil studi yang dilakukan oleh Nababan (dalam Slamet 1999: 44) terhadap guru-guru di Jakarta menunjukkan bahwa peran buku teks sebagai sumber belajar siswa sangat dominan dan termasuk faktor penting agar proses pembelajaran berlangsung dengan baik. Keberadaan buku ajar tidak saja memudahkan guru dalam merancang dan melaksanakan pembelajaran tetapi juga membantu siswa agar mereka dapat mempersiapkan diri sebelumnya. Mengingat pentingnya peranan buku ajar dalam pembelajaran maka perlu dikembangkan penelitian tentang buku teks yang saat ini masih sangat terbatas. Selain itu pengembangan buku ajar kimia yang kontekstual diharapkan dapat membantu agar proses pembelajaran kimia di sekolah menjadi aktif dan menyenangkan, relevan dengan tujuan dan berlangsung secara efektif dan efisien.

Tujuan Analisis kebutuhan ini adalah

1) Mengidentifikasi kebutuhan bahan ajar dalam pembelajaran IPA khususnya kimia setelah diberlakukannya kurikulum tingkat satuan pendidikan/KTSP atau yang dikenal dengan kurikulum 2006,

2) Mengetahui materi yang menurut guru sulit diterima oleh siswa

3) Mengidentifikasi masalah-masalah dan kendala-kendala pembelajaran yang dihadapi guru dalam pembelajaran kimia. Hasil analisis kebutuhan ini akan dipakai untuk mengembangkan bahan ajar yang memiliki karakteristik pencapaian kompetensi siswa sesuai dengan kurikulum 2006 yang berlaku sehingga prinsip dasar dan tujuan dalam kurikulum dapat tercapai.

\section{Kajian Teori}

1. Bahan Ajar

Pengertian bahan ajar (instructional materials) merupakan rincian spesifikasi isi yang memberikan panduan bagi guru dalam hal intensitas /kedalaman materi dan jumlah perhatian yang dituntut oleh suatu materi tertentu atau tugas-tugas pedagogis. Atau secara sederhana dapat dikatakan bahan ajar adalah berbagai sumber belajar yang dapat dimanfaatkan secara langsung ataupun tidak langsung untuk kepentingan pembelajaran (Sri Hayati, 2000:23). Sedangkan menurut Dick \& Carey (1996:229) bahan ajar merupakan seperangkat materi/substansi pelajaran yang disusun secara sistematis, menampilkan sosok utuh dari kompetensi yang akan dikuasai peserta didik dalam kegiatan pembelajaran. Bahan ajar dapat berupa informasi berbentuk tulisan atau suatu media yang digunakan peserta didik untuk mencapai tujuan pembelajaran.

Bahan ajar merujuk kepada segala sesuatu yang digunakan guru atau siswa untuk memudahkan belajar, untuk meningkatkan pengetahuan dan atau pengalaman belajar. Sedangkan pengembangan bahan ajar adalah apa yang dilakukan penulis, guru atau siswa untuk memberikan sumber masukan berbagai pengalaman yang dirancang untuk meningkatkan belajar. 
Dalam tulisannya Sri Hayati (2000:23) membedakan Bahan ajar dalam dua kelompok yaitu :

a. Bahan ajar utama atau bahan ajar pokok yang menjadi rujukan wajib dalam suatu rangkaian kegiatan pembelajaran seperti buku teks, modul, hand out dan bahan-bahan panduan utama lainnya.

b. Bahan ajar penunjang (supplementary reading materials) yaitu bahan lain yang keberadaannya sebagai pelengkap dan pengayaan seperti buku bacaan, majalah, program video, leaflet, poster, komik instruksional dan lainnya.

Diantara kedua macam bahan ajar tersebut, buku merupakan salah satu komponen penting dalam kegiatan pembelajaran terutama pada jenjang pendidikan dasar dan menengah karena buku ajar sering dianggap sebagai refleksi kurikulum, materi yang disajikan didasarkan pada materi yang ada dalam kurikulum. Dan dalam pelaksanaannya disekolah guru hanya memberikan tambahan penjelasan berdasarkan apa yang ada dalam buku ajar karena diasumsikan buku ajar yang digunakan telah sejalan dengan kurikulum.

Studi terdahulu oleh Dedy Supriadi (2000:35) mengungkapkan bahwa buku ajar merupakan penentu yang signifikan terhadap hasil belajar siswa SD. Dalam perannya yang sangat dominan sebagai sumber belajar, buku ajar disusun berdasarkan pertimbanganpertimbangan tertentu. Diantaranya buku ajar disusun dan disesuaikan dengan materi pelajaran maupun pertimbangan aspek kemampuan atau perkembangan kognitif siswa.

Pendapat lain disampaikan oleh Ella Yulaelawati (1994:5) yang menyatakan buku ajar sebagai sarana penting untuk menyampaikan informasi dan pesan-pesan tertulis kepada siswa dalam proses pembelajaran paling tidak harus menawarkan tiga bentuk kategori kegiatan belajar yaitu : a) menggali dan mengkaji ilmu pengetahuan dan teknologi, b) berlatih keterampilan termasuk ketrampilan belajar lebih lanjut dan c) berlatih ketrampilan menerapkan pengetahuannya dalam berbagai konteks. Perkembangan ilmu pengetahuan yang sangat pesat menuntut agar buku ajar dapat direvisi untuk disesuaikan dengan perkembangan zaman sehingga buku tetap bisa dijaga aktualitasnya. Buku ajar yang baik adalah buku yang tidak memiliki kesalahan. Umumnya kesalahan berhubungan dengan aspek bahasa dan substansi.

Pada tingkat sekolah dasar dan SMP masih dijumpai penulis buku yang mengunakan bahasa yang terlalu mementingkan konsep keilmuan tanpa mengindahkan kemampuan siswa untuk menyerapnya. Pada hal ide dasar pengadaan buku adalah untuk membantu proses pembelajaran siswa. Penulisan buku ajar tidak semata-mata menyajikan bahan bacaan demi untuk ilmu pengetahuan. Sebaliknya penulisan buku ajar sekolah memiliki misi untuk mengemas konsep ilmu pengetahuan ke dalam bahan dan program belajar. Konsekuensinya penulis harus dapat memilih dan menyusun kata-kata yang mudah dipahami oleh siswa sesuai dengan tingkat usianya.

Upaya mendapatkan buku ajar yang baik telah ditindak lanjuti Pemerintah dengan mengeluarkan Peraturan Menteri Tahun 2005 Nomor 11 Pasal 3 ayat 1 yang menyatakan bahwa "buku teks pelajaran untuk setiap mata pelajaran yang digunakan pada satuan pendidikan dasar dan menengah dipilih dari buku-buku teks pelajaran yang telah ditetapkan oleh Menteri berdasarkan rekomendasi penilaian kelayakan dari Badan Standar nasional pendidikan (BSNP)".

Kriteria buku yang baik menurut Peraturan Menteri tersebut adalah buku yang dapat dipakai baik dari segi isi maupun fisik buku, 
dalam masa kurun waktu paling sedikit lima tahun. Kurun waktu lima tahun dimaksudkan supaya bisa mengakomodasi perubahanperubahan yang bermakna dalam perkembangan ilmu pengetahuan dan teknologi, dan pertimbangan dari segi ekonomi bagi pengguna.

Adapun komponen yang dijadikan fokus penilaian buku ajar adalah(BSNP 2006:1):

a. Komponen Kelayakan Isi

Komponen ini mencakup 7 sub komponen yaitu (1) cakupan materi, (2) Akurasi materi, (3) Kemutakhiran,

Mengandung wawasan produktivitas, (5) Merangsang keingintahuan/ curiosity, (6) mengembangkan kecakapan hidup/ life skills, serta (7) Mengembangkan wawasan ke-Indonesiaan/ kontekstual.

b. Komponen kebahasaan

Ada 7 sub komponen kebahasaan yaitu (1) sesuai dengan perkembangan peserta didik, (2) komunikatif, (3) dialogis dan interaktif, (4) lugas, (5) koherensi dan keruntutan alur pikir (6) kesesuaian dengan kaidah bahasa Indonesia yang benar dan (7) Penggunaan istilah dan symbol / lambang.

c. Komponen Penyajian

Dalam komponen penyajian, ada 3 sub komponen yang harus dinilai yaitu (1) teknik penyajian, (2) Pendukung penyajian materi serta (3) Penyajian pembelajaran.

d. Komponen Kegrafikaan

Sesuai dengan namanya, maka komponen yang dinilai adalah (1) ukuran buku, (2) desain, tata letak, tipografi, dan ilustrasi bagian kuli serta (3) desain, tata letak, tipografi, dan ilustrasi bagian isi.

\section{Pengembangan bahan Ajar yang}

Kontekstual.

Bila kita melihat kompetensi pembelajaran sains dalam kurikulum 2006, maka kompetensi yang diharapkan pada kakikatnya bermuara pada empat keterampilan pokok yang mencakup keterampilan personal, keterampilan sosial, keterampilan akademik dan keterampilan vokasional. Karena itu buku ajar yang berorientasi kurikulum 2006 juga harus memenuhi keempat parameter tersebut dan dalam hal ini pendekatan kontekstual sangat cocok untuk diterapkan.

Bahan ajar dengan pendekatan kontekstual didesain dengan mengkoordinasikan antara content (materi pelajaran) dan keterampilan intelektual yang harus dimiliki siswa. Tentu saja dipertimbangkan pula kondisi dan situasi yang cocok dengan kemampuan kognitif siswa dan kepentingan lingkungan belajarnya supaya siswa dapat mengaplikasikan pengetahuannya dalam dunia nyata.

Menurut Sutejo (Kompas 2003), ada beberapa hal yang perlu diperhatikan dalam penyusunan buku ajar berdasarkan kurikulum 2006 ini:

a. Buku ajar hendaknya memberikan ruang pembelajaran, penggalian, yang dapat membangkitkan potensi diri, bakat dan kemampuan personal siswa supaya dapat berkembang secara maksimal.

b. Buku ajar hendaknya mampu menciptakan materi yang dapat menggiring siswa untuk menyadari potensi sosialnya, seperti kemampuan untuk berinteraksi sosial, bekerja sama dengan orang lain.

c. Materi-materi dalam buku ajar hendaknya terorganisasi dengan baik untuk mewujudkan keterampilan akademik siswa dengan memberikan ruang kepada siswa agar menggali kecakapan aplikatifnya atas pengetahuan kognisi yang dimilikinya.

d. Buku ajar diharapkan juga bisa menyediakan materi yang merangsang atas tumbuh dan berkembangnya keterampilan vokasional. 
Disisi lain, Adun Rusyana (2003) mengemukakan buku sains berbasis pembelajaran kontekstual hendaknya memperhatikan tiga hal yaitu content, budaya dan hakikat sains yang bisa dijabarkan sebagai:

a. Content (materi pelajaran) memiliki struktur, prinsip dan material. Struktur berfungsi untuk membantu guru menetapkan kompetensi standar dan pengayaan dari materi itu. Material membawa sejumlah muatan keterampilan intelektual (pengetahuan, pemahaman, aplikasi, analisis, sintesis, evaluasi)

b. Budaya.

Budaya merupakan unsur penting dalam pendidikan. Salah satu fungsi penting budaya yang harus mendapat perhatian saat menyusun bahan ajar adalah fungsi preservasi dinamik yaitu menggali unsur-unsur essensial dari kebudayaan dan membuka diri terhadap unsurunsur positif dari luar.

c. Hakikat Sains

Buku sains hendaknya memiliki nilai seni sehingga siswa bisa menikmati dan tertarik untuk mempelajarinya. Tampilan gambar, grafik, bagan yang jelas dalam bahan ajar merupakan daya tarik tersendiri.

\section{Analisis kebutuhan}

Untuk mengembangkan bahan ajar perlu dilakukan analisis kebutuhan supaya yang dihasilkan sesuai dengan kebutuhan pemakai dilapangan. Castelle G. Gentry (1994:12) menerangkan kebutuhan atau need sebagai :" need is a gap between a desired outcome and observed outcome".

Selanjutnya Kaufman, Rojas dan Mayer(1995) menyatakan sebagai berikut : Needs are gap between our current results and payoffs and those we could or should have".
Bertitik tolak dari pengertian kebutuhan yang telah dikemukakan para ahli tersebut diatas maka dapat disimpulkan bahwa kebutuhan adalah kesenjangan antara apa yang ada dengan apa yang seharusnya ada atau kesenjangan antara kenyataan dan harapan.

Menurut Kaufman, analisis kebutuhan dapat dirumuskan sebagai suatu usaha untuk mengidentifikasi alat dan metode yang diperlukan dalam rangka menghilangkan kesenjangan antara kenyataan dan harapan.

Menurut JE Kemp ada dua hal yang perlu diperhatikan untuk menentukan apakah pengembangan pembelajaran perlu dilaksanakan atau tidak yaitu :

a) Dengan mengidentifikasi perkembangan situasi dalam bidang yang diminati. Ini mungkin melibatkan upaya penelitian pembelajaran yang sedang diberikan ditempat lain.

b) Membandingkan data yang terkumpul dengan yang seharusnya terjadi. Perbedaan antara apa yang ada dengan yang dikehendaki dapat dipakai sebagai alasan terbaik untuk memutuskan apakah pengembangan model pembelajaran perlu dilakukan atau tidak.

Dalam melakukan analisis kebutuhan untuk pengembangan materi atau bahan pembelajaran perlu diperhatikan dan dibedakan antara target needs (kebutuhan sasaran ) dan learning needs (kebutuhan belajar). Target needs menyangkut tindakan apa yang diperlukan siswa agar memenuhi pengetahuan dan kemampuan yang perlu dikuasai. Sedangkan learning needs menyangkut tindakan apa yang diperlukan pembelajar agar siswa dapat belajar.

Dalam rangka memenuhi target kebutuhan perlu dikumpulkan berbagai informasi yang dapat diperoleh dengan jalan menyebar kuesioner, melakukan pengamatan, wawancara, analisis buku teks yang telah ada 
dan melakukan konsultasi informal dengan para ahli, siswa dan orang lain yang dapat memberikan informasi yang diperlukan dalam rangka pelaksanaan analisis kebutuhan.

Jadi yang dimaksud dengan analisis kebutuhan adalah suatu kajian terhadap aspek-aspek apa yang dibutuhkan para siswa, komponen-komponen dan sarana apa yang diperlukan agar mereka dapat mencapai tujuan seperti yang diharapkan.

\section{Tujuan Analisis kebutuhan}

Dalam kaitannya dengan pengembangan model pembelajaran, Castelle G. Gentry (1994:14) menyatakan bahwa analisis kebutuhan bertujuan untuk :

a. Identifikasi dan menentukan adanya masalah /kesenjangan antara apa yang ada dan yang diharapkan

b. Analisis masalah : Mengetahui kebutuhan pembelajaran dan memberikan informasi awal mengenai apa yang diperlukan untuk pengembangan model pembelajaran.

c. Menyelesaikan masalah dengan menentukan skala prioritas, melaksanakan lebih dahulu bagianbagian yang dianggap penting sedangkan yang dianggap kurang penting dilakukan kemudian.

Dalam kaitannya dengan penelitian ini tujuan analisis kebutuhan adalah untuk :

a. Mengidentifikasi kebutuhan belajar siswa SMP dalam pembelajaran sains/ IPA

b. Mengklarifikasi topik yang akan dipilih sebagai bahan ajar

c. Mengidentifikasi masalah/kendala yang dihadapi guru dalam pelaksanaan pembelajaran kimia

d. Mencari sumber belajar yang dapat dipakai untuk menunjang pelaksanaan pembelajaran e. Mengidentifikasi nilai-nilai yang bisa ditanamkan kepada siswa dalam pembelajaran kimia.

\section{Langkah-langkah Analisis kebutuhan}

Menurut Kaufman, untuk melakukan analisis kebutuhan secara umum ada beberapa langkah yaitu :

a. Identifikasi kebutuhan :

Dalam mengidentifikasi kebutuhan peneliti harus selalu memperhatikan karakteristik peumusannya. Disini kebutuhan dirumuskan dalam bentuk hasil yang dapat diukur yang menunjukkan kesenjangan antara keadaan yang ada dengan keadaan yang diinginkan. Kegiatan ini dapat dilakukan melalui berbagai cara antara lain pengamatan, wawancara, angket dan catatan laporan.

b. Penentuan prioritas : macam-macam kebutuhan yang telah diidentifikasi kemudian disusun dalam urutan prioritas

c. Kriteria seleksi penyusunan kebutuhan menurut prioritas:

Dalam langkah ini diterapkan kriteria seleksi sebagai alat untuk menseleksi kebutuhan

d. Penentuan kebutuhan yang akan dipenuhi

Jika kebutuhan yang telah diseleksi sama-sama mendapat prioritas yang tinggi untuk segera dipenuhi maka patokan yang digunakan adalah hal-hal profesional yang mengacu pada kebutuhan tersebut.

\section{METODE PENELITIAN}

Untuk mencapai tujuan seperti diatas, diadakan penelitian dengan mengambil sampel secara teknik purposive sampling. Data dikumpulkan dengan menggunakan angket dan respondennya adalah guru IPA SMP kelas 
1. Selanjutnya data yang telah terkumpul dianalisis secara kualitatif dan kuantitatif.

\section{HASIL PENELITIAN DAN PEMBAHASAN}

Angket analisis kebutuhan yang disebarkan ke guru SMP menunjukkan bahwa yang mengajar kimia adalah guru Biologi dan guru Fisika (untuk semua sekolah yang di survey). Dan diantara responden belum ada yang mengikuti pelatihan untuk pembelajaran kimia di sekolah. Ini menujukkan bahwa dalam pembelajaran kimia guru hanya mengacu pada buku ajar yang ada. Berdasarkan angket diketahui juga bahwa demonstrasi dalam pembelajaran jarang dilakukan oleh guru. Selanjutnya $66,7 \%$ responden menyatakan bahwa jumlah jam pelajaran yang disediakan untuk materi kimia tidak cukup (kurang banyak). Pengembangan silabi dan rencana pembelajarannya dibuat dalam musyawarah guru sains /MGMP (33\%) sedangkan guru yang lain (67\%) cukup dibahas antara guru sains di sekolah. Untuk mengoptimalkan waktu yang ada perlu bahan ajar yang dapat membantu guru dan siswa dimana kegiatan pembelajaran benar-benar disesuaikan dengan waktu dan materi (ada pembagian yang rinci antara teori, praktek dan tugas) sehingga waktu yang terjadwal dapat dimanfaatkan dengan baik.

Berkaitan dengan topik yang dianggap sulit dan perlu diprioritaskan dalam pengembangan bahan ajar, sebagian besar responden menyatakan bahwa topik asam, basa dan garam, serta reaksi kimia perlu didahulukan karena penting, dan sangat dekat dengan kehidupan sehari-hari siswa.

Sehubungan dengan kendala-kendala yang dihadapi guru dalam pembelajaran kimia, hambatan terbesar guru (88,9\%) adalah alokasi waktu yang terbatas untuk mencapai kompetensi siswa, kesulitan guru dalam menentukan alokasi waktu ini mempunyai komposisi yang sama dengan kesulitan dalam menyusun rencana pembelajaran sains kimia (77,8\% responden ) karena masih banyak guru yang belum mendapat kesempatan untuk mengikuti pelatihan pembelajaran kimia. Hal lain yang menjadi kendala adalah kurangnya jumlah guru sains $(55,6 \%)$, terbatasnya buku sains kimia yang kontekstual (33,3\%), kurangnya buku perpustakaan sekolah yang menunjang pembelajaran kimia dan praktikum kimia (55,6\%).

Mengenai buku sains-kimia, responden menginginkan buku sains kimia yang memberikan banyak contoh dalam kehidupan sehari-hari /kontekstual (100\%) dengan materi yang cukup luas /tidak dibatasi dari kurikulum saja $(77,8 \%)$.

\section{KESIMPULAN}

Berdasarkan hasil penelitian dan pembahasan maka dapat ditarik kesimpulan sebagai berikut:

a Bahan ajar yang diinginkan guru dalam pembelajaran sains-kimia di SMP adalah yang memberikan banyak contoh dalam kehidupan sehari-hari /kontekstual dengan materi yang cukup luas/tidak dibatasi dari kurikulum saja.

b Topik yang perlu diprioritaskan adalah asam - basa dan garam, serta reaksi kimia Dalam hal ini muatan materi diangkat sesuai dengan realitas kehidupan seharihari yang dijumpai siswa karena selain lebih mudah dipahami juga dapat menarik minat siswa dalam belajar.

c Kendala yang dihadapi guru antara lain terbatasnya jam pelajaran kimia, guru kesulitan membagi alokasi waktu antara fisika/biologi dan kimia serta tugas rangkap yang diberikan kepada guru ( karena belum ada guru kimia di SMP) menyebabkan pelaksanaan pembelajaran sangat tergantung pada keberadaan buku ajar disekolah.

d Untuk mengembangkan bahan ajar diperlukan suatu prosedur yang harus diikuti dengan cermat dengan mempertimbangkan hasil yang diperoleh dari masing-masing tahap terutama tahap analisis kebutuhan. 


\section{DAFTAR PUSTAKA}

Badan Standar Nasional Pendidikan. 2006. Instrumen Penilaian Buku Teks Pelajaran Pendidikan Dasar dan Menengah. Jakarta. BSNP. Hal 1.

Borg, Walter R. and Gall, M.D.,1983. Educational Research: An Introduction. $4^{\text {th }}$ ed. New York: Longman Inc.

Departemen Pendidikan Nasional. Peraturan Mendiknas Nomor 11 Tahun 2005 tentang Buku Teks Pelajaran. Jakarta. 2006.

Direktorat PLP Depdiknas, 2002. Pendekatan Kontekstual (Contextual Teaching and Learning). Jakarta: Proyek Peningkatan Mutu SLTP.

Djudin, Tomo. 2003. Buku Teks Sains : Kriteria dan Bentuk Masa Depan. Mimbar Pendidikan. 2 (XXII) 31- 36

Ella Yulaelawati dkk. 1994. Penulisan Bahan-Bahan Pelajaran. Pusat Pengembangan Kurikulum \& Sarana Pendidikan. Jakarta. Hal 5

Gentry, Castelle G. 1994. Introduction to Instructional Development: Process and Technique. California: Wadsworth Publishing Company. Hal 12

Karhami,S. Karim. 1996. Peranan Buku Paket dalam Menjembatani Kesenjangan antara Dokumen Kurikulum Tertulis dengan Pelaksanaannya. Kajian Dikbud. 3(1) 34-42.

Pannen,Paulina dan Purwanto (2001). Penulisan Bahan Ajar. Jakarta :PAU-PPAI Dirjen Pendidikan Tinggi,Depdiknas.

Rusyana, Adun. 2003. Pedoman Penulisan Buku Sains Berbasis Contextual Learning. Pusat Perbukuan, Departemen Pendidikan Nasional.

Sapari, Achmad. 2004.( 8 November). Buku Pelajaran dalam Perspektif Kultural. http://www.kompas.com.

Semiawan, Conny. 2003. Penelitian dan Pengembangan Dalam Pendidikan : Makna, Tujuan dan Konteksnya. Makalah disampaikan dalam Pelatihan Metodologi Research and Develoment. Jakarta: Lembaga Penelitian UNJ.

Supriadi, Dedi. 2000. Problematik dan Opsi kebijakan tentang Buku Teks Sekolah Dasar. Mimbar Pendidikan 2 (XIX).35-46

--, 2006. Standar Mutu Isi dan Grafika dalam Penilaian Buku Teks Pelajaran 2006. Makalah. IKAPI DKI Jakarta, BSNP, PUSBUK.

Wiyanto dkk. 2007. Potret Pembelajaran sains di SMP dan SMA. Jurnal Pendidikan dan Pengajaran Undiksha. No.2 Th XXXX. April 2007 hal 389.

Slamet,1999. Analisis Buku Teks IPS SMP di Kodya Surakarta. Paedagogia. No. 1/1999 hal 4.

Sri Hayati,2000. Pengembangan Bahan Ajar Berorientasi Kehidupan dan Alam pada Jenjang SLTP. Pelangi Pendidikan. Vol 5 No. 1 hal 23.

Sutejo. 2003. Parameter Buku Berorientasi KBK. Kompas 22 Des. 2003.

Walter Dick dan Lou Carey. The Systematic Design of Instruction. New York : Longman,1996 hal 229

Kaufman, Alice Rojas, dan Hanna Mayer. 1995. Needs Assesment: A User's Guide. Englewood Cliffs, New Jersey: Educational Technology Public. 